Received: June, 2016

Accepted: December, 2017

ISSN $2006-6996$

\title{
A PROXIMATE, MINERAL COMPOSITION AND ANTI-NUTRITIONAL FACTORS OF THE AERIAL PARTS OF Lablab purpureus (L.) SWEET
}

\author{
*Abdullahi Sulaiman ${ }^{1}$ and Muhammad Abubakar Lawal ${ }^{2}$ \\ ${ }^{1}$ College of Agriculture and Animal Science, Division of Agricultural Colleges, \\ Ahmadu Bello University Mando, Kaduna-Nigeria. \\ ${ }^{2}$ Department of Chemistry, Ahmadu Bello University Zaria, Kaduna-Nigeria. \\ *Corresponding Author: abdulskargi@yahoo.co.uk GSM No.+2348036790734.
}

\section{ABSTRACT}

This study evaluates the nutritional and anti-nutritional potentials of the aerial part of Lablab purpureus as it relates to its use in Animal nutrition. The preliminary phytochemical test of the plant revealed the presence of bioactive secondary metabolites; glycosides, saponins, flavonoids, tannins, steroids, alkaloids, coumarins, phenols, carbohydrates and terpenoids in the crude extract. Results from the study revealed significant mineral composition in Lablab purpureus. Atomic Absorption Spectroscopic (AAS) technique was employed in the elemental analysis. Substantial amounts of $\mathrm{Ca}, \mathrm{Na}, \mathrm{K}$ and $\mathrm{Mg}$ were found, while $\mathrm{Cu}, \mathrm{Fe}, \mathrm{P}, \mathrm{Mn}$ and $\mathrm{Zn}$ were present in trace amounts. Proximate analysis revealed the ash and fat contents to be $5.6 \%$ and $4.2 \%$ respectively. The protein level, total Carbohydrate and Fibre contents were determined to be $25.4 \%, 46.93 \%$ and $7.5 \%$ respectively. The presence of anti-nutritional secondary metabolites; tannins, saponins, oxalates, phytates, cyanogenic glycosides and free phenolics were quantitatively determined to be $0.50 \%, 3.8 \%, 0.70 \%, 2.2 \%, 1.2 \%$ and $2.1 \%$ respectively. The results of the phytochemical constituents, proximate composition, anti-nutritional factors and mineral composition of the aerial part of Lablab purpureus in this study demonstrates high nutrients content with potentials to meet the nutritional requirements in monogastric diets.

Key words: Anti-nutritional composition, Lablab Purpureus, Mineral composition, Proximate analysis.

\section{INTRODUCTION}

Lablab purpureus known as beans in English 'wake' in Hausa and 'ewa' in Yoruba belongs to the Fabaceae family and is cultivated in many countries of the world including west tropical Africa, and Nigeria in particular. It is a legume that thrives very well in Northern Nigeria. It is drought resistant and is usually sown after the normal cropping season, thereby acting as a buffer crop for ruminant feeding during the dry season (Adu et al., 1992). Lablab purpureus is a common plant cultivated for its edible beans, though it is reported to have certain medicinal properties (Handa et al., 1989; Adeleke et al., 2012). One common cause for the high cost of raising animals in the developing countries is the high cost of feeding ingredients, and poor feeding strategies (Shaahu et al., 2012). It is apparent that the demand for animals' diet in developing countries like Nigeria is on the rise. This is pertinently stabilized by the increase in the production of the minor legumes, many of which have low preference or are unsuitable for human consumption, and thus, reducing the over dependence on conventional feed stuff (Shaahu et al., 2012). Therefore, the need for increase in animals' production in such countries like Nigeria must require the exploitation of the non-conventional feed ingredients. One such legume that could be exploited to serve as an alternative source of nutrients in monogastric diets is the leaves of Lablab purpureus (Cameron, 1988).

It is against this background that this study aimed at evaluating the nutritional value of the aerial part of
Lablab purpureus. The objectives are therefore to determine its phytochemical constituents, proximate composition, anti-nutritional factors and mineral composition.

\section{MATERIALS AND METHODS}

Plant Material Collection and Identification Aerial parts of Lablab purpureus (L.) sweet (Subsp. bengalensis) were collected during September 2016 from Kargi district, of Kaduna state, and taxonomically identified at the Herbarium, Ahmadu Bello University Zaria (Adebisi and Bosch, 2004).

Preparation of Methanolic Extract of Aerial Parts

Aerial parts were washed thoroughly with distilled water to remove dust and other particulate matter, cut into small pieces, air-dried in the shade, and 150g of dried and powdered aerial parts were extracted with methanol (Trease and Evans, 1996).

Preliminary Phytochemical Screening

Portion of the methanol extract was subjected to preliminary phytochemical screening using standard procedures (Sofowora, 1993; Trease and Evans, 1996; Silva et al., 1998).

Proximate Analysis

Moisture, ash, proteins, fat and crude fibre contents were determined according to standard procedures outlined in Williams (1984). Total carbohydrate was calculated by difference according to Williams (1984) procedure. 


\section{Mineral Analysis}

The sample was ashed and the residue dissolved in hydrochloric acid and quantitatively transferred into a volumetric flask. The volume was made up to $50 \mathrm{ml}$ using distilled deionised water. The concentrations of the mineral elements ( $\mathrm{Ca}, \mathrm{Na}, \mathrm{K}, \mathrm{P}, \mathrm{Cu}, \mathrm{Fe}, \mathrm{Mg}, \mathrm{Mn}$ and $\mathrm{Zn}$ ) were determined using Atomic Absorption Spectrophotometer (Alpha 9 Model, Buck Scientific Ltd USA) according to the method outlined by Williams (1984).

\section{Anti-Nutritional Analysis}

Total tannins were determined colorimetrically as described in AOAC (1990). The method described by
Day and Underwood (1986) was adopted for the determination of oxalates and phytates. Gravimetric method of AOAC (1990) was employed to quantitatively determine saponins.

\section{RESULTS AND DISCUSSION \\ Preliminary Phytochemical Screening}

The phytochemical screening of the aerial part of the plant Lablab purpureus revealed the presence of carbohydrate, glycosides, alkaloids, saponins, steroids, terpenoids, coumarins, phenols, flavonoids, and tannins (Table 1).

Table 1: Phytochemical Constituents of Crude Methanol Extract of the aerial Part of Lablab purpureus

\begin{tabular}{llc}
\hline Phytochemicals & Tests & Inference \\
\hline Glycosides & $\begin{array}{l}\text { Modified } \\
\text { Bontrager's } \\
\text { Lead acetate }\end{array}$ & + \\
Tannins & Ferric Chloride & + \\
Saponins & Frothing & + \\
Anthraquinones & Bontrager's & - \\
Flavonoids & NaOH & + \\
Steroids/Triterpenes & Lieberman- & + \\
& Burchard & \\
Alkaloids & Dragendoff's & + \\
& Wagner's & + \\
Coumarins & Picric acid & + \\
Phenols & & + \\
Carbohydrates & & + \\
Terpenoids & Molisch's & + \\
\hline
\end{tabular}

Key: $\quad+=$ Present $\quad-=$ Absent

The presence of glycosides, saponins, flavonoids, tannins, steroids, alkaloids, coumarins, phenols, carbohydrates and terpenoids in the plant materials called for immense research, since bioactive chemical compounds (secondary metabolites) are of various pharmacological importance.

Several reports have provided evidence for the pharmacological effects of plant phytochemicals. Tannins are reported to have anthelmintic effects (Molan et al., 2000) and useful in the treatment of inflamed or ulcerated tissues and they also have remarkable activities in the cancer prevention and anticancer activity (Akinpelu et al., 2009). Flavonoids, phenols and saponins have been reported to exhibit their actions through effects on membrane permeability, anti oxidative action and anti inflammatory effects (Olayinka and Okoh, 2010). Many triterpene saponins and their aglycones have varied uses including anti-inflammatory, antipyretic, fibrinolytic, analgesic, anti-ulcerogenic, anti-oedema and antimicrobial effects (Hostettmann and Martson, 1995; Soetan et al., 2006; Ndukwe et al., 2007). Alkaloids are haemolytically active, toxic to microorganisms and are widely used as therapeutic agents in the management of cancer. Glycosides are reported to inhibit tumour growth and also protect against gastrointestinal infections (Adeshina et al., 2010). Terpenoids have been reported to be active against bacteria, fungi, protozoa and viruses (Maiyo et al., 2010). El-Mahmood et al. (2008) linked antimicrobial properties of plants to bioactive secondary metabolites (saponins, tannins, alkaloids, flavonoids, phenols, glycosides and diterpenes).

\section{Proximate Composition}

Data on the dry matter, ash, fat, protein, fibre and carbohydrate constituents in the aerial part of the plant (Lablab purpureus) sample are shown in Table 2. The dry matter was determined to be about $88.2 \%$.

Table 2: Proximate Composition (\%) of the Aerial Part of Lablab purpureus

\begin{tabular}{ll}
\hline Constituents & Relative amount \\
\hline Dry Matter (\%) & $88.20 \pm 0.40$ \\
Moisture Content (\%) & $11.80 \pm 0.20$ \\
Ash Content (\%) & $5.60 \pm 0.10$ \\
Crude Fat (\%) & $4.20 \pm 0.30$ \\
Crude Protein (\%) & $25.40 \pm 0.20$ \\
Crude Fibre (\%) & $7.50 \pm 0.20$ \\
Ethyl Ether (\%) & $5.87 \pm 0.4$ \\
Total Carbohydrate (\%) & $46.93 \pm 0.30$ \\
\hline
\end{tabular}

Data are mean of triplicate determinations \pm standard deviation 
The ash and fat contents were $5.6 \%$ and $4.2 \%$ respectively. The Moisture content was determined to be $11.8 \%$, which agree with data reported previously by Al-Snafi (2017). The protein level, total Carbohydrate and Fibre contents were determined to be $25.4 \%, 46.93 \%$ and $7.5 \%$ respectively. These results are comparable with those reported by Shaahu et al. (2012).

\section{Minerals Composition}

Nine (9) minerals were found, which include calcium, sodium, potassium, copper, iron, phosphorus, magnesium, manganese and zinc. These minerals are regarded as the most significant elements of a valuable food (Murphy et al.,1999).

Table 3: Minerals Composition (mg/100g) of the Aerial Part of Lablab purpureus

\begin{tabular}{cc}
\hline Minerals & Concentration $(\mathbf{m g} / \mathbf{1 0 0 g})$ \\
\hline $\mathbf{C a}$ & $36.5 \pm 0.020$ \\
$\mathbf{N a}$ & $71.6 \pm 0.008$ \\
$\mathbf{K}$ & $112.6 \pm 0.012$ \\
$\mathbf{C u}$ & $1.4 \pm 0.002$ \\
$\mathbf{F e}$ & $155.3 \pm 0.003$ \\
$\mathbf{P}$ & $386.6 \pm 0.007$ \\
$\mathbf{M g}$ & $156.8 \pm 0.020$ \\
$\mathbf{M n}$ & $20.5 \pm 0.008$ \\
$\mathbf{Z n}$ & $30.4 \pm 0.004$ \\
\hline
\end{tabular}

Data are mean of triplicate determinations \pm standard deviation

Table 3, shows that the aerial part of Lablab purpureus has high content of the following essential minerals; Iron (Fe), Phosphorus (P), Potassium (K) and Magnesium (Mg), with the following concentrations; $155.3 \mathrm{mg} / 100 \mathrm{~g}$, $386.6 \mathrm{mg} / 100 \mathrm{~g}$, $112.6 \mathrm{mg} / 100 \mathrm{~g}$ and $156.8 \mathrm{mg} / 100 \mathrm{~g}$, respectively. While relative amount of Sodium $\mathrm{Na}$, about 71.6 $\mathrm{mg} / 100 \mathrm{~g}$; Calcium (Ca), about $36.5 \mathrm{mg} / 100 \mathrm{~g}$ and Zinc (Zn), about $30.4 \mathrm{mg} / 100 \mathrm{~g}$ were also found to be present in the sample, Manganese (Mn), and Copper (Cu) recorded the least with the following concentrations; $20.5 \mathrm{mg} / 100 \mathrm{~g}$ and $1.4 \mathrm{mg} / 100 \mathrm{~g}$ respectively. This implies that the aerial part of $L a b l a b$ purpureus could be a good dietary mineral supplement for animals. This agrees with the study of Al-Snafi (2017), in his review reported that Lablab purpureus is rich in some micronutrients with considerable variation depending on the variety.

\section{Anti-Nutritional Composition}

The anti-nutritional composition of the aerial part of Lablab purpureus is presented in table 4. Six (6) factors which include tannins, saponins, oxalates, phytates, cyanogenic glycosides and free phenolics were quantitatively determined.

Table 4: Anti-nutritional Composition $(\mathrm{mg} / \mathrm{g})$ of the Aerial Part of Lablab purpureus

\begin{tabular}{lc}
\hline Constituents & Composition $(\mathbf{m g} / \mathbf{g})$ \\
\hline Tannins & $0.50 \pm 0.02$ \\
Saponins & $3.80 \pm 0.01$ \\
Oxalates & $0.71 \pm 0.02$ \\
Phytates & $2.20 \pm 0.01$ \\
Cyanogenic glycosides & $1.20 \pm 0.03$ \\
Free phenolics & $2.10 \pm 0.02$ \\
\hline
\end{tabular}

Data are mean of triplicate determinations \pm standard deviation

The concentrations of tannins, saponins, oxalates, phytates, cyanogenic glycosides and free phenolics in the aerial part of Lablab purpureus are $0.50 \%, 3.8$ $\%, 0.70 \%, 2.2 \%, 1.2 \%$ and $2.1 \%$ respectively. Saponins had the highest percentage composition while oxalate had the least. High composition of oxalate in human diet can increase the risk of renal calcium absorption and has been implicated as a source of kidney stones (Chai and Liebman, 2004). In addition, Chai and Liebman (2004) reported that higher value of tannins in feeds interferes with protein absorption and digestive enzymes. From the results obtained in this study, the concentrations of oxalates, tannins and phytates in the aerial part of Lablab purpureus are low to cause any health risk in both human and animals.

\section{CONCLUSIONS}

Finally, the results of the phytochemical constituents, proximate composition, anti-nutritional factors and mineral composition of the aerial part of $L a b l a b$ purpureus in this study demonstrate that it contains high nutrients with potentials to meet the nutritional requirements in monogastric diets. It can also be used as a dietary supplement to correct some nutritional deficiencies. According to the International Feed Industry Federation standard, the low concentrations of anti-nutritional factors also suggest that the aerial part of Lablab purpureus is a good source of food for both human and animals (I.F.I.F., 2017).

\section{REFERENCES}

A.O.A.C. Association of Official Analytical Chemist (1990). Official Method of Analysis. 16th ed: William Tryd Press washinton D.C. USA. Chapter 4 pp. 17-34.

Adebisi, A. A. and Bosch, C. H. (2004). Lablab purpureus (L.) sweet. Retrieved from http://www.prota4u.org/search.asp 
Adeleke, O. E., Soetan, K. O. and Fasasi, K.A. (2012). Antimicrobial Activities of Three Varieties of Lablab purpureus seeds. Recent Progress in Medicinal Plants, 32:419-432.

Adeshina, G. O., Onaolapo, J. A., Ehinmidu, J. O. and Odama, L. E. (2010). Phytochemical and Antimicrobial studies of the ethyl acetate extract of Alchornea cordifolia leaf found in Abuja, Nigeria. Journal of Medicinal Plants Research, 4(8):649-658.

Adu, I. F., Fajemisin, B.A. and Adamu, A. M. (1992). The utilization of sorghum stover fed to sheep as influenced by urea and graded levels of lablab supplementation. In: Small Ruminant Research and Development in Africa. Proceedings of the 1st Biennual Conference of the African Small Ruminant Research Network, ILRAD, Nairobi, Kenya. Pp. 367-374.

Akinpelu, D. A., Aiyegoro, O. A. and Okoh, A. I. (2009). The bioactive potentials of two medicinal plants commonly used as folklore remedies among some tribes in West Africa. African Journal of Biotechnology, 8(8):16601664.

Al-Snafi, A. E. (2017). The pharmacology and medical importance of Dolichos lablab (Lablab purpureus): A review. IOSR Journal of Pharmacy, 7(2): 22-30.

Cameron, D. G. (1988) Tropical and Subtropical Pasture Legumes. Queensland Agricultural Journal, pp.110-113.

Chai, W. and Liebman, M. (2004). Assessment of Oxalate Absorption from Almonds and Black Beans with and without the use of Extrinsic Label. Journal of Urology, 172:953-957.

Day, R. A.(Jnr.) and Underwood, A. L. (1986). Quantitative Analysis. 5th ed. Prentice Hall Publication, pp.701.

El-Mahmood, A. M , Doughari, J. H. and Ladan, N. (2008). Antimicrobial screening of stem bark extracts of Vitellaria paradoxa against some enteric pathogenic microorganisms. African Journal of pharmacology, 2(5):089094.

F.A.O. Food and Agriculture Organisation of the United Nations (2014). Grassland Index. A Searchable Catalogue of Grass and Forage Legumes. FAO, Rome, Italy. Retrieved from http://www.fao.org./ag/AGP/AGPC/doc/GBASE /commonname/commonsearch.htm

Handa, S. S., Chawla, A. S. and Maninder, K. (1989). Hypoglycaemic plants. A Review. Fitoterapia. 60(3): 195.

Hostettman, K. and Martson, A. (1995). Saponins. Cambridge University Press, Cambridge, U.K.

I.F.I.F. International Feed Industry Federation (2017). Retrieved from http://www.ifif.org
Maiyo, Z. C., Ngure, R. M., Matasyoh, J. C. and Chepkorir, R. (2010). Phytochemical constituents and antimicrobial activity of leaf extracts of three Amaranthus plant species. African Journal of Biotechnology, 9(21):31783182.

Molan, A. L., Duncan, A., Barry, T.N. and McNabb, W.C. (2000). Effects of condensed tannins and sesquiterpene lactones extracted from chicory on the viability of deer lungworm larvae. Proceeding of New Zealand Society of Animal Production, 60:25-29.

Murphy, A. M. and Colucci, P. E. (1999). A tropical Forage Solution to Poor Ruminant Diet. A Review of Lablab purpureus. Livestock Research and Rural Development. Retrieved from http://www.Irrd.org/lrrd11/2/colu112.htm.

Ndukwe, G. I., Amupitan, J. O., Isah, Y. and Adegoke, K. S. (2007). Phytochemical and Antimicrobial Screening of the Crude Extracts from the Root, Stem Bark and Leaves of Vitellaria paradoxa. African Journal of Biotechnology, 6(16):19051909.

Olayinka, A. A. and Okoh, A. (2010). A preliminary phytochemical screening and in vitro antioxidant activities of the aqueous extract of Helichrysum longifolium. BMC Complementary Alternative Medicine, 10(21):18.

Shaahu, D. T. Ikurior, S. A. and Carew, S. N. (2012) Proximate Chemical and Mineral Composition of Different Varieties of Raw Lablab purpureus Seeds. Proceedings of the 17th Annual Conference of the Animal Science Association of Nigeria. Abuja ASAN-NIAS Joint annual meeting. pp.651-654.

Silva, G., Lee, I. and Kinghorn, A. (1998). Special Problem with the Extraction of Plants. Humana Press, New Jersey. pp. 1-48.

Soetan, K. O., Oyekunle, M. A., Aiyelaagbe, O. O. and Fafunso, M. A. (2006). Evaluation of the antimicrobial activity of saponins extract of Sorghum bicolor L. Moench. African Journal of Biotechnology, 5(23):2405-2407.

Sofowora, A. (1993). Medicinal Plants and Traditional Medicine in Africa. $2^{\text {nd }}$ ed. Spectrum Books Ltd., Ibadan, Nigeria. pp. 130-289.

Trease, A. and Evans, W. C. (1996). Pharmacognosy. $14^{\text {th }}$ ed. W.B. Saunders Company. UK. pp. 50425.

Williams, S. (1984). Official Methods of Analysis. Association of Official Analytical Chemists. AOAC Inc., Arlington. 